\title{
The Unsivilized Figure as Cultural Hero of Artifice: Suassuna’s JoÃo Grilo and Twain’s Huck FinN
}

BENJAMIN CHAFFIN

\section{Abstract}

In their close ties to a folkloric past, and in a conscientious effort to dialogue with a far-reaching literary inheritance, the Brazilian Ariano Suassuna (1927-2014) and the U.S.s Mark Twain (1835-1910) present regional protagonists who negotiate roles as heroes of artifice. As they feed off models of the Trickster and picaro, an analysis based on cognitive and psychosocial theory reveals a João Grilo and Huck Finn that model valued skills as socioeconomically marginalized figures on the outskirts of civilization. In Auto da Compadecida (1955) and Adventures of Huckleberry Finn (1884), both Suassuna and Twain manage to highlight these skills by creating character duos that mimic the cognitive counterpointing between Miguel de Cervantes' Don Quijote and Sancho Panza.

KeYwords: Ariano Suassuna. Mark Twain. Trickster. Pícaro. Marginalized figures.

On attending the theatrical debut of Auto da Compadecida in Madrid, Pedro Laín Entralgo noted a deep Cervantine sensibility in Ariano Suassuna's work. Taking the Aragonese's observation to heart, the playwright returned to the Quijote and a reconsideration of the Novelas Ejemplares, as they connect to the masterwork he had created adapting material from the literatura de cordel of his native Northeastern Brazil (2008, p.182). In what Suassuna relates, this rereading focused primarily on how Cervantes' central text might interact with a European tradition blossoming into the original picaresque genre, just a few years after the publication of the first part of Guzmán de Alfarache. Admittedly, the picaresque has

Professor leitor na Universidad de los Andes, entre 2014 e 2016, e na University of Hawai'i, entre 2016 e 2017.

E-mail: chaffin@ucsb.edu Orcid iD: https://orcid.org/0000-0003-0737-6521 
become an exceedingly varied and broad concept. ${ }^{1}$ However, particularly in light of the literary moment, Suassuna's interpretation becomes a clear redefining of terms and a reading of Cervantes through the lens of the Northeastern popular tradition. Rather than homing in, for example, on the novella Rinconete $y$ Cortadillo, the Quijote's Ginés de Pasamonte, or signaling out cunning traits in squire and self-appointed knight, Susassuna produces a non-traditional reading of Sancho Panza, pronouncing him a picaro, ${ }^{2}$ in contrast to Don Quijote (2008, p. 182).

The Spanish picaresque of the $16^{\text {th }}$ and $17^{\text {th }}$ centuries builds in large part on the structure of the romance de caballería, infusing it with a new anti-hero. This type of anti-hero, as Márquez Villanueva argues, is made possible through the literatura del "loco" or bufonesca tradition coming out of $15^{\text {th }}$ century Spain, reincorporating a Lucian sensibility into the heavily rational Humanism of the $13^{\text {th }}$ and $14^{\text {th }}$ centuries $(1985$, p. 510). In the Quijote, Cervantes goes a step further to create his own palimpsest on the picaresque, dialoging with it in his restoration of the knight errant, now rendered quixotic in his Caballero de la Triste Figura. Rather than focus on the agent and trailblazer of the journey, Suassuna is instead drawn to the scheming, socioeconomically marginalized, and often manipulative squire as the correlative of his Northeastern muse. "Vi," he writes, "que Dom Quixote é um sonhador, como Chicó (mentiroso lírico, alucinado pelo sol do Sertão), e que Sancho Pança é um pícaro, como João Grilo" (2008, p. 182). Suassuna, likewise, in an assertion that reflects a prioritization of fusion, and his professed cantador bricolage, argues that cordel figures who survive by their wit, such as Pedro Quengo and João Grilo, have as much in them of the Iberian picaro as they do the gracioso of Siglo de Oro theater (2008, p. 177). Even when Suassuna later finds, in the form of the novel,

1 In their survey of this term, Kent and Gaunt address Claudio Guillén's work on a sensu stricto and sensu lato picaresque, and the need to bridge the duality of the term, revitalizing it for use with the "novel in lands and times other than that of the Spanish Renaissance" (1979, pp. 250251).

2 Canavaggio avoids the term picaro while portraying Sancho as a flexible character, even rising above his cunning and comic relief on a spectrum between "bellaco" and "truhán." 
the means to make his scheming protagonist an autobiographical narrator when writing A Pedra do Reino, a faithful echo of the original Spanish template is subsumed in his synthesis of a variety of forms. ${ }^{3}$

With significant alterations, parallels to the Iberian picaresque, sensu stricto, do indeed abound in Auto da Compadecida (1955) and Suassuna's other works. These include 1) variations on the episodic structure; 2) the figure of lower station's survival by wits; 3 ) the initial destitution of the main character, though in this case deprived of vertical mobility or biographical progression; and 4) a tendency toward Juvenalian satire, which Suassuna is frequently at work to limit, shifting toward the Horatian and Menippean. Yet these conventions overlap with other influences and are secondary to a broad and extensive process of amalgamation in the crucible of the Northeastern popular tradition. In his 1958 meta-analysis of the cordel tradition that demonstrates his focus, Suassuna designates, as one of six categories, his own conception of a "ciclo cômico, satírico e picaresco" (2008, p. 175). Among the various salient influences feeding the cordel tradition is that of the traveling cantador, as a descendant of the juglar or jogral of the Iberian oral ballad tradition. This figure, whom Suassuna aspires to, gives an additional dimension to the upstart hero, mirroring and serving as a cognitive counterpoint to the extemporaneous cunning of the protagonist in third person. The writing poets, or poetas de bancada, in a region that was ninety percent illiterate in many rural areas up into the first half of the $20^{\text {th }}$ century (SLATER, 1982, p. 22), have recorded stories of the Northeastern oral tradition that date, in prototypical form, as far back as $8^{\text {th }}$-Century Europe (VASSALLO, 1993, p. 71). As Suassuna points out with the gracioso, the folheto also reflects a variety of Renaissance and Baroque elements, perhaps most notably in the auto sacramental, evolving out of a medieval tradition. Prohibited in the $18^{\text {th }}$ century in the Peninsula, it continued embedded and mutating in the culture of the Sertão. Suassuna, on reading Anatol Rosenfeld's analysis of

In calling A Pedra do Reino a picaresque novel while writing it, he leaves friend and fellow Northeasterner Rachel de Queiroz somewhat confused with the evolved usage of the term when she is finally able to read it (QUEIROZ, 2017, p. 25). 
medieval and Renaissance conventions in Auto da Compadecida, felt the need to point out that these influences came to him through the folhetos and espectáculos of his native Paraíba. "Tudo isso, em minha peça," he writes, "vem do Bumba meu boi, do Mamulengo, da oralidade dos desafios de Cantadores e mesmo de autos populares religiosos" (2008, p. 179).

Effectively, European literary forms-themselves closely connected to and derivative of popular traditions - were transitioned into a Northeastern popular and folk setting ${ }^{4}$, where they become Suassuna's source material. This metamorphizing is further complicated by the writer's broad reading of texts that served as their original source material. Not only does his writing bring to bear, for example, Gil Vicente's work, but draws on a network and contextualization that spans much of Europe and goes at least as far back as Menander. This suggests a doubled and reflexive layering of influence with - if his reading of the Quijote is an indicationthe primacy of the Northeastern context. As regards this additional layer of influence, Lygia Vasallo highlights, among other examples, the handling of a balance of the sacred and profane, as well as more faithful uses of medieval archetypes, including the Trickster of the European Carnival tradition, and Bakhtin's accompanying world turned upside down (1993, pp. 51-52). Many protagonists of the cordel, in outsmarting their hierarchical superiors, reflect just such an inverted schema of the latter. ${ }^{5}$

However, beyond medieval archetype or picaro, these characters often reflect not just a Brazilian popular adaptation but an initial folkloric source. This is indeed the case of João Grilo, who as a figure has his origins in stories of the Iberian Peninsula. As Francisco Topa observes, the animal monikers of both João Grilo and João Ratão, stem out of a close association with old folk fables in which the characters are their eponymous animals (1995, p. 8). In the Northeastern tradition, then, Grilo

4 With Santos' discussion as a point of departure (1999, pp. 15-16), popular here is taken to mean production, reception, and exchange focused on the socioeconomically lower masses of a particular population - a contrast with high art. Folk, reflective of regional collective knowledge, exists as the product of an oral tradition.

5 Slater maps out this inversion in her structuralist metasurvey of the genre (1982, p. 60). 
is originally more of a folkloric alteration of the Trickster that is similar to figures like Pedro Malasartes and established in line with allegorical sensibilities. The folk João Grilo is effectively placed in a tradition that has, in an expectedly complex and diverse process, increasingly popularized medieval, Renaissance, and Baroque forms, while at the same time absorbing a wide range of material from a variety of periods and places. In this amalgamation he seems to even reflect a device, time out of mind, seen in indigenous or Classical Tricksters like Hermes, as when, in the As Proezas de João Grilo (1951), an expansion by João Martins de Ataíde, he seems nearly born with the ability to deceive and manipulate (2005, p. 117). He will, in addition, answer the Riddle of the Sphinx when asked by Sultão Bartolomeu of Egypt, and in a variation on the One Thousand and One Nights, rob thieves from Mecca. Grilo, as he becomes Suassuna's character, overlaps with the picaro in the Trickster traits that Victoria Gay Simmons enumerates, including "behavior from or in opposition to the cultural norms;" and "Id-centered behavior" connected to greed and sex (2005, p. 2). Yet as trickster ${ }^{6}$, the positionality and, hence, the function of these traits often becomes altered.

Vassallo observes that like those of the medieval theater, Suassuna's dramatic characters tend to be "estereotipados" or flat (1993, p. 32). This fits into a naturally vertical conversation with influences, rather than a horizontal one, within the context of the legitimization of the Armorial project. This, however, is partially a means of maintaining Trickster qualities, and by extension, connections to the folkloric and popular, while transplanting a character like João Grilo into the contrasting environment of $20^{\text {th }}$-century theater. Parallel to the Quijote, and the source material it dialogues with, the first two acts ${ }^{7}$ of Suassuna's play offer a contrasting mimetic environment that simulates the quotidian. This then becomes

6 Here a spelling distinction is acknowledged between an archetypal "Trickster" of the longstanding folkloric tradition, and a broader notion of "trickster" that accommodates more modern adaptations and incarnations.

7 I am using the Palhaço's entrances as act markers, with the auto and Grilo's return to Earth grouped together. 
an appropriation of older high art conventions in an effort to continue reconciling what Franz Boas describes as the prototypical Trickster's "purely egotistical" motives and the role of "popular hero" (1940, p. 409). While the allegorical better accommodates the potential contradictions that this entails, Suassuna is challenged with finding a balance between the folk figure and characters that face everyday consequences. In short, Suassuna pulls the Northeastern trickster that fed off the picaro as one of many sources back into his version of the pícaro and a realism (in his first two acts) closely associated with the realism that gave rise to the original genre. This, as can be seen in Márquez Villanueva, parallels the formation of the original picaresque genre rising out of the literatura del "loco," established in the $15^{\text {th }}$ century. "Construida con abundantes materiales folklóricos," he writes, addressing the tradition, "es aquí donde creadoramente consuma también su afinidad con la tradición de cuentos, proverbios y cantares proprios del lenguaje de la locura en su época" (1985, p. 521). Suassuna in his own iteration, faces the problem of the culturally affirmative status of both his hero and the Armorial project. As Guillén points out, the pícaro sensu stricto, as a figure, is effectively a representation of alienation. "It presents," he writes, "the growth and alienation of an homo interior, and demonstrates his ability to consider with endless ambiguity the simplified career of homo exterior" (1971, p. 93). In application, this makes having a close friend or sidekick difficult (1971, p. 97). If the Armorial Movement is to reaffirm a nordestinidade in a geographical, historical, and mythical space (Santos, 1999, p. 19), the Northeastern trickster must continue to epitomize social engagement through theory of mind, undermining social norms while embracing social solidarity.

While older literary forms are less dominant in Mark Twain, Adventures of Huckleberry Finn (1884), likewise, presents a picaresque processed and infused with popular tradition, placed in the framework of the bildungsroman. With adaptations of the Spanish picaresque dating back to the end of the $16^{\text {th }}$ century in the British Isles, by the time characteristics of the English-language rogue appear in U.S. Southwestern Humor of the early- and mid- $18^{\text {th }}$ century, the figure has a porous connection to the 
folkloric. Emphasized by its opposition to more highly regarded literature that romanticizes what was then the U.S. Southwest-Arkansas, Missouri, Mississippi, etc.-the genre's sensibility aligns itself more closely with popular types and forms such as the tale. As the heir of the tradition, Twain, like Suassuna, seeks to express and celebrate regional identity by bringing its popular literature into the realm of high art. It is notable that he too seeks to achieve this through a vertical dialogue with a European past that includes Cervantes. In his inherited chronology, once the knight errant survived his journey across a potentially fantastic landscape, through esteemed virtue and justified violence. In the Southwestern hero, such as Tom Owen or a literary Davy Crockett, the trials are reduced to exaggeration and conquered through plotting and a backwoods physical acumen reflective of a prowess needed in a weakly civilized landscape.

In surviving their episodic trials or run-ins, these at times uncultured and half-wild U.S. figures present varying combinations of a mixture that draws from, on one end, the physical manipulation of their environment and, on the other, talents more closely akin to the rogue, as exemplified in J.J. Hooper's Simon Suggs. As in Twain, this space becomes ripe for the deceptive figure as it fosters the faith and trust of its people in the project of civilization, while its anemic nature creates a lack of self-monitoring and vulnerability to aberration. As a cognitive folk lesson, its deceptive figure accentuates an ability to deviate from scripts, which vastly dominate our mental processing, and from which we rarely deviate, activating the network in the brain that allows for idiosyncratic understanding through theory of mind (APPERLY, 2012, p. 117). This theory of mind acts as a foundation for social deception in that it allows us to conceptualize the varying intentions of others $(2012$, p. 9). It is in this sense that the folk trickster's violation of social norms takes on an instructive component, suggesting an interpersonal sophistication ready for when the other may deceive. Read as a bildungsroman, Huck's development, incorporation, and the limitations he sets to these skills become central to Twain's novel.

What does this mean in Suassuna's weakly-civilized Sertão, where Machiavelli's lion and fox so clearly rule? This is the space of a hard life, 
where upward mobility is as much a dream as Sancho Panza governing an island. As Slater argues, the folheto, in its inversion of power dynamics, is effectively a kind of escapism that functions by "willfully glossing over the contradictions all too apparent in day-to-day relationships" (1982, p. 217). The João Grilo of Proezas grows out of a prankster youth characterized by mischief for mischief's sake by robbing thieves and ascends to a Solomon-like position. However, moved from both the initial amoral landscape of prankster and his escapist rise to power in far-off lands to Suassuna's theater, he is presented with just such a day-to-day reality, in which his negotiations and survival mirrors that of the common individual. Overcoming this challenge potentially gives him a double relevance as hero. As in Jung's conception of the trickster, it is not so much that Grilo is a one-to-one character-to-human model, but a collection of essential traits ordinarily confined to the shadow (1981, p. 270) — just as the literatura del "loco" is about recovering part of a cognitive spectrum. Here it must reconcile the ability to triumph celebrated in the folktale; elevate the poor nordestino without corrupting his identity; and align with an Armorial agenda. Like Huck Finn as Southwest hero, Grilo's dexterity and understanding of deception, become central, exalted traits, connected to an identity particularly centered around a pride in surviving in a hard land. Both authors preserve a connection to folk and popular models by reframing the character, reworking his deceptive impact, and-parallel to Cervantes - creating a duo in which a sidekick bears the brunt of an inventive, marvelous and semi-demiurgical element previously allowed in the allegorical.

Whether it is werewolves roaming Paraíba, people flying on a peacock, or Lampião facing the devil, the world of the cordel often heightens the marvelous component of the folkloric. In the tradition of the Trickster figure itself, this can also manifest itself cosmologically in his capacity as semi-demiurge. Though the auto is brought into this schema, Suassuna's João Grilo, when Earth-bound in his representation of the common man is - unlike his cordel incarnation-trapped in the more realistic role of 
impoverished bakery assistant. Auto da Compadecida, in this way echoes the realistic moralizing cordeis of Leandro Gomes de Barros from which the first two acts draw. At the same time the connection to the broader sensibility of the cordel and the marvelous aspects of trickster, recorded in the Proezas de João Grilo, are preserved in the play by the duo established with Chicó. In the Quijote, the delusional knight errant, moving into the growing realism of the Spanish literary moment, brings a literary marvelous past into the present, offset by Sancho, who in his lower-class struggles offers a counterpoint of popular wisdom. Part of the allure and power of trickster figures like Huck and João Grilo is that they shadow the more traditional Trickster's semi-demiurgical powers in creating and controlling scenarios. In the mimetic setting this is done through cognitive complexity that exercises control over their environment, rather than marvelous aspects of their character. A power stems from complicated induction as regards intentions (many-to-one mapping) (APPERLY, 2017, p. 9) as well as the ability to easily leap back and forth from theory-rule constructs to theory-theory constructs. Suassuna, like Cervantes, then preserves the perceived marvelous by setting it up in opposition to his trickster. The formation of the Grilo-Chicó duo allows for its humorous and celebrated incorporation with Grilo's sidekick bearing much of the weight.

When we first meet João Grilo and Chicó, it is en media res, moving focus to understanding the deception that Grilo is orchestrating, as well as ascertaining his possible intentions. While it is a typical technique for forms like the domestic drama, here it reaffirms their allegorical existence and, meeting them in flagrante delicto suggests a continual and repetitive behavior. As part of the nascent plan, Chicó has apparently gone to fetch Padre João with the intention of having him deliver last rites to a dead dog. On Chicó's return, Grilo asks, "E ele vem mesmo? Estou desconfiado, Chicó" (1971, p. 25). Here "desconfiado," as with Hooper's Simon Suggs, could function as one of his personal mottos. It is a celebration of a suspicious and skeptical popular attitude. At the same time, it establishes both a power dynamic with Chicó as the teller of tall tales that celebrates 
Grilo's cunning in theory of mind. We can infer a Chico who continually legitimizes himself to the protagonist. "Eu, sem confiança?" he says. "Que é isso João, está me desconhecendo?" (1971, p. 25). As Grilo doubts whether or not the plan will come to fruition and Padre João will bless the deceased dog despite fear of his bishop, Chicó adds, "Eu mesmo já tive um cavalo bento" (1971, p. 26).

As Chicó tells his story of riding his cavalo bento after a heifer-and, as it turns out, an ox, as well—several hundred kilometers to Propriá, two basic marvelous elements of the cordel stand out. First, less realistic cordeis, like Proezas, in their allegorical mode, in a process sometimes akin to visual folk art, continually break down the spatial-temporal component, minimizing vast distances and journeys which, in some cases, creates an interplay between the Sertão and far-off lands and times. Second, it is perhaps without surprise that the vaqueiro culture of the Northeast moves into the marvelous in cordeis like História do Boi Misterioso in which cowboy figures can become shape-shifting specters and the often-central figure of the ox can, among other attributes, defy realistic travel—as Chicó does here. What's more, Chicós story of the "blessed" horse, paralleled to Padre João's blessing in the main plot, shows a popular culture equivalence, seen in cordeis, between the stricter sense of a religious blessing and what might be more accurately considered types of enchantment or magic. As Chicós improbable story unfolds, Grilo becomes the transgressive-like trickster, attacking its vagueness, and details - but positioned in the realism of the low mimetic, challenging Chicós story through specificity that does not exist in the allegorical. This perhaps reaches its height, when Grilo, following his expert theory of mind pattern enters Chicós perspective and uses hyperbole to corrupt his friend's story. "Quando você teve o bicho?" he asks, "E foi você quem pariu o cavalo, Chicó?” (1971, p. 27).

As types of variation on invention, Suassuna presents a cognitive process of fantasy separated from an ability to plot, deceive, and manipulate. In this model, Chicó will eventually elicit a kind of awe, but with little effect in convincing others. When the dog is finally buried at the end of Act 1, Chicó is there for his friend Grilo, who warns the sacristan that not 
blessing the dog would leave it to haunt them. Chicó confirms, with an elaborate and unconvincing story. He relates dropping ten tostões in the Cosme Pinto river, which his dog goes after, seemingly consulting a ghost dog. The coin comes back-as if he has been given change by spiritsas two cruzados (1971, p. 66). This is a problem connected to Dennett's intentional stance, which he defines as "a system whose behavior can beat least sometimes - explained and predicted by relying on ascriptions to the system of beliefs and desires (and hopes, fears, intentions, hunches, ...)" (2017, p. 1). In full episodes within a tale, the supernatural or marvelousthough sometimes in a tantalizingly vague way-provides the ascription of a coherent system, behind which there is an intention. If João Grilo's great, celebrated skill is understanding intention through theory of mind, Chicó cannot even produce it in his inventions. The baker who is listening, responds, “Oi! E essas almas de lá têm dinheiro trocado?" (1971, p. 66). As the baker points out, the story lacks any ascribable intention that might overcome Occam's Razor.

Chicó also tells a story about being dragged by a pirarucu for three days and nights in the Amazon River, in the same vein as the story about his horse, and (discussed) later he has a brief burst of untethered quixotic insight. Otherwise, he conforms to social norms and piety, playing the reluctant role of frightened straight man in Grilo's scheming. He takes a backseat as the Baker's wife and Severino replace him, tricked by Grilo into magical interpretations of a cat that defecates money and a harmonica that brings people back to life. When Grilo dies and enters the afterlife with the others in Act 3, the suggestion of the marvelous in the expectation of a mimetic Sertão is inverted as Grilo's down-to-Earth quizzing and insolence is secondary to the expected mythic mode of the trial of his soul. In this scenario Chicó is no longer necessary, though when Grilo comes back to life, it will be Chicó's obedient piety that prevents Grilo from becoming rich.

In Proezas, João Grilo leaves school after outsmarting his teachers and is left to provide for his widowed mother crying "por necessidade" (2005, p. 99). When in the mata, he overhears the thieves from Mecca 
and concocts a plan in which he robs them by pretending to be dead and having himself buried in a coffin at the Belém Chapel-their rendezvous site to split up their gains. When he bursts out of the coffin, he shouts, “Esperem por mim que eu vou / com as ordens de Jesus!” (2005, p. 102). This money, which he brings home to his mother puts an end, by means of the metaphorical death of his youth, to their intense struggle to survive. In this passage out of his circumstances, he can no longer function in the Sertão but must go to a far-off land where his inferior position is retained by going head-to-head with Bartolomeu do Egito.

The shift in Tom Sawyer from the first novel, The Adventures of Tom Sawyer (1876), to the second novel (Adventures of Huckleberry Finn), is admittedly, in some ways baffling. However, it can be partially explained by the death of his youth and a kind of death of some of his attributes as trickster. When Tom and Huck overhear Injun Joe's gang and discover their gold, it is after going out-in play-to discover treasure. In developmental terms, childhood play becomes real, paralleling a transition into young adulthood and initiation into society. Tom, too, will cultivate the faking of his death, which ends in his recovering the thieves' gold in a new location. The money from the find totals $\$ 12,000$ and is split between them, with Huck - as he explains at the beginning of the second novel-receiving half through a trust with Judge Thatcher as he lives with the Widow Douglas. When the money establishes a dynamic in which he becomes a mark for his peripheral father to take advantage of, he tries to give the $\$ 6,000$ to the judge (1964, p. 751). In this dynamic with Pap, his instinct to resist entrance into the mainstream culture of a disappearing periphery is brought to the fore.

This provides the context for an evolving power dynamic between the pair of friends. Tom, who is the ringleader of the boys in the first novel, in a way, becomes clearly more assimilated into mainstream society and school. When Huck first decides to "light out" and abandon the Widow Douglas, it is Tom who finds him, and with simple grandiosity, offers to initiate him into the fantasy of his gang of thieves. It is not that Tom has lost his ability to scheme or manipulate toward a goal, but as he is initiated 
more and more into educated society, effectively moving upward, this creative power shifts toward the pole of Chicó and Don Quijote. He and Huck, in this sense, move away from each other on two branching roads. Eventually, Huck and the others quit the gang feeling held back by the inability to move into play that Tom is trying to legitimize through his adventure books. Huck objects to one fantasy by saying:

"I didn't see no di'monds, and I told Tom Sawyer so. He said there were loads of them there, anyway; and he said there was A-rabs there, too, and elephants and things. I said, why couldn't we see them then? He said if I warn't so ignorant, but had read a book called Don Quixote, I would know without asking. He said it was all done by enchantment" (1964, p. 748).

In the first novel, Tom spoke of stories and the exotic elements, such as pirates, but his fantasies become more and more literary, as his schemes become increasingly useless. Here, the delineation between artifice and marvelous invention comes full circle. The marvelous entering the realistic adult realm must be subsumed into impractical literature. In contrast to Tom, João Grilo, after manipulating the bishop into going along with blessing the dog for six contos, shows that he cannot read when it comes time to alter the figures of the will to match his victory.

As the plot of the novel unfolds, Huck shows an incredible ability to survive by his wits-in, perhaps, a more impressive way than Tom Sawyer ever did. At the same time, he frequently asks himself, even sometimes inviting Jim to participate, what Tom might have done in the situation. For example, he stages his own complex homicide (that mirrors the planning and matter-of-factness of the character Davy Crockett) managing to flee captivity with Pap, but immediately regrets being incapable of giving it "the fancy touches" of Tom Sawyer (1964, p. 764). There is a self-doubt and even guilt in Huck, a sense of inferiority, despite his skill, for resisting his induction into respectable society. Eventually, when the two are reunited at the Phelps Farm toward the end of the book, the project becomes liberating Jim. When Tom delays the process many days, citing various literary conventions that 
must be followed, the dynamic between the two of them shifts. Without the same aggressiveness, he begins to mentally question Tom, as Grilo does Chicó. Perceiving Tom's ineffectualness facilitates his final moving away from boyhood and toward the power of João Grilo. Given that unlike the Grilo of Proezas, he cannot head off to Egypt-or a marvelous version thereof-he lights out for California (1964, p. 969).

The funeral for the dog of the first act of Auto da Compadecida adapts the cordel $O$ Dinheiro: $O$ Testamento do Cachorro by Leandro Gomes de Barros. It lacks a protagonist, other than money as a corrupting force, which "impera sobre um trono / Cercado de ambição" (2016, p. 42). The family unit is corrupted as a brother and sister marry, and a priest accepts money to deliver the last rites to a pet, though, in this case, it is a foreigner's dog. Adapting this situation to João Grilo's machinations and making it the dog of the baker's wife, effectively creates a situation in which he would function more as a classic picaro, in which corruption is embraced for survival and personal gain in a pervasively corrupt system, and therefore warranted. However, Suassuna alters this potential construct by infusing the scene with new motive.

As the action unfolds, we eventually ascertain that he is not crafting this plan as either a favor or to ingratiate himself with the wife of his patrão. Grilo, instead, becomes the poor worker striking back via the values of the historical honor system of the Sertão. He seeks revenge for his work conditions and the baker's wife essentially treating the dog, who he is having buried, better than him. "A fraqueza dela," he says to Chicó, who has had an affair with her, "é dinheiro e bicho" (1971, p. 38). It is important that his plan does not come to fruition to maintain the role of the character (who is small, weak and vaguely echoes the grotesque element of the Trickster). As Boas notes, the end the Trickster seeks is "selfish to the extreme, the possession of riches or that of beautiful women being his chief aim" (1940, p. 409). He continues, "It is difficult to harmonize these two aspects of the myths of the culture hero" (1940, p. 409). While never realized, Grilo's plan is an affirmation of an honor 
society in which a person defends their status and seeks justice beyond the channels of anemic or ineffective institutions, frequently absent-as they are with the later arrival of Severino. He adds, as well, that he does not like Padre João either and that part of his scheming is out of personal spite and an ability to hold a grudge. Effectively, his selfish motives as Idbehavior, coupled with conventions of honor, mitigate the social critique. Meanwhile, to maintain his identity as popular hero, his victories where money is concerned must come to a zero-sum game. Divorced from the delusional, grandiose element of the Trickster, he wins in his scheming, but in a Trickster manner does not reap any benefit.

While Grilo's trickery is generally convincing-and to great comic effect. As a cognitive representation he continues to exist in basic faithfulness to the "Advinha Advinhão" aspect of Proezas in that he is a kind of cognitive fantasy. $\mathrm{He}$ is not so much unrealistic in reasoning itself, as thinking detectives in the tradition of C. Auguste Dupin or Sherlock Holmes, who present exciting illusions that claim to be plausible sophisticated mental feats. However, as Suassuna strings together trials from various cordeis, he remains inexhaustible. Jeffrey Walczyk et al model this as activation-decisionconstruction-action theory. In it we face an impromptu situation in which we are presented with the option of deceiving; weigh the value of telling the truth against lying; consider the plausibility of a possible construction; and evaluate whether we can get away with the execution. Grilo is, of course, so preternaturally good at construction and action, that neither the activation nor the decision has a relevancy.

Going one step further, David Livingstone Smith posits that the largely unconscious operation of our faculties has, in part, evolved to support participating in complex social groups. His conception of a society in which we must constantly deceive reflects Twain's 1880 speech "On the Decay of the Art of Lying." "Everybody lies," writes Twain, "every day; every hour; awake; asleep; in his dreams; in his joy; in his mourning; if he keeps his tongue still, his hands, his feet, his eyes, his attitude, will convey deception - and purposely" (1985, p. 504). Based on cognitive studies, Livingstone Smith argues that our

8 This serves primarily as an initial provocation, as Twain goes on to focus on variations of the platonic noble lie. It is worth noting that he lost the speech competition. 
primarily unconscious thinking allows us to deceive others to participate in society by deceiving ourselves without consciously knowing it (2007, p. 3). Not being consciously aware of the deception is a way of overcoming the Pinocchio Problem that would signal deception to the group and bring a variety of ramifications. However, Livingstone Smith writes, "self-deception has a price tag attached: it helps us help ourselves to ill-gotten social gains, but it also deprives the conscious mind of potentially useful information" (2007, p. 77). Grilo does deceive himself as to self-insight and outcomes of his scheming, but primarily, as preserved trickster in the mimetic environment, he is a joyful fantasy that merges the unconscious and the conscious, constantly deceiving without keeping information from himself. Huck as cognitive trickster is presented in the context of the bildungsroman, in which the choices that impact his personal development have profound impact. In what could be called his final temptation to opt for educated, proper society, he struggles both with cognitive overload-reflective of his age and more realistic mental limitations - as well as the guilt he begins to feel for taking advantage of people.

The Wilks, and Mary Jane particular, represent the potential goodness that established society can provide. As Robert Evans points out in his separation from Jim on the river, Huck is a trickster very much capable of getting tricked himself-and feeling guilty about it (2010, pp. 3-4). Lisa Zunshine points out, as well, that it is a development in theory of mind in Huck that enriches the book's early scenes with the Widow Douglas, as Huck manages to infer the widow's actual empathetic intentions (2019, p. 13). At the Wilks, his actions have the cover of going along with the King and the Dauphin as actual conmen, and his sense of embarrassment preserves his popular values as he struggles to go along with a scheme pretending to be their relatives from England. His lack of knowledge about where he is supposed to be from leaves him vulnerable to the equally precocious Joana's acuity at the dinner table. When, for example, Huck insists that he attends the same church as William IV (who actually died in 1837), Joana points out that the King of England lives in London, while the confidence men had said they lived in Sheffield (1964, p. 874). The problems with his narrative only get worse from here, as, to 
cover up his falsities, he varies off into descriptions of imported saltwater baths that the King takes in London. In the moment in which Mary Jane scolds Joana for impertinent questions, Huck says, "I felt so ornery and low down and mean" (1964, pp. 876-877). He describes Mary Jane as "awful beautiful, and her face and her eyes was all lit up like glory" (1964, p. 867). In short, Huck falls for her, and the challenge is reconciling his behavior with her qualities of natural trust, decency, and sensitivity. Part of what is essential to the portrait of Suassuna's Grilo as common man of the Sertão is continually striving to make the money that will alter that status - and thus can never happen. Huck's story involves much more freedom, and, it is likely, less destitution, accommodating developmental choices, and so Mary Jane appears as a legitimate opportunity to change. While she is significantly older than he is, she represents a seminal, final chance-the possibility of partnering with someone (even if it is not her) and choosing a domestic route. In the moment of fleeing with his life from her town, Huck runs past her window and contemplates the light in her window that he does not expect to see again.

In contrast to Huck's limited artifice, Grilo is ready to handle Suassuna's succession of challenges in Act 2. When he asks the baker's wife if she is now "mais consolada," with the rites for her pet, she continues to focus just on the money (1971, p. 91). "Consolada?" she asks, "Como, se além de perder meu cachorro, ainda tive de gastar treze contos para ele se enterrar?” (1971, p. 91). Grilo in typical calculating fashion has foreseen this failure and already has his next scheme ready, borrowed from Gomes de Barros' O Cavalo que Defecava Dinheiro. In this folheto, a man whose family is on the point of starvation tricks a caricature of a greedy fazendeiro into buying an old ailing horse, by stuffing coins in its backside and convincing him that it excretes money. Here the dynamic is closer to the model of the classic picaro as well, with the anonymous ranch hand rising in status. Working along the lines of a pet replacement, Grilo makes the money-producing animal a cat, and in a scene with just the two of them, the baker's wife takes over the role of counterpoint dreamer after initial hesitation: "João, me arranje esse gato pelo amor de 
Deus" (1971, p. 97). What ensues is a fake negotiation that leaves Grilo with five hundred réis.

As Severino, an amalgamation of various incarnations of the Sertão's cangaceiro, arrives, the second half of Gomes de Barros' folheto plays out. Here Grilo faces the lion, in a showdown of might against wit. The bandit's force becomes his vulnerability, as he understands the world only through killing and dying. Grilo, knowing the dog's bladder is rigged up with blood for another potential trick, finds the thugs weak spot as he is about to be shot, offering him a magic harmonica. "Para que eu quero uma gaita?" Severino asks (1971, p. 121). The trickster responds, "Para nunca mais morrer dos ferimentos que a polícia lhe fizer” (1971, p. 121). Severino now becomes the dreamer as Grilo stabs the dog's bladder on Chicó's person, faking his death and echoing a scene from the Quijote. It is Severino's turn to dream and believe in the marvelous. $\mathrm{He}$ is so convinced, that he insists on being shot to test the harmonica's powers. This is an underdog adaptation of the folheto in that, in a rather brutal way, the rich fazendeiro falls for buying an enchanted rabeca, hoping to save his dying wife.

While João Grilo's artífice works, he stays to go after the money from the will, giving a cangaceiro that he and Chicó have jumped the opportunity to shoot him. The subsequent trial for his soul is a brilliant way of returning the Northeastern auto to the stage. While the folhetos it is based on are somber and related to salvation, here the auto is about Grilo's shamelessness and a reversal of the realistic contextualized in the marvelous. That being said, the framework of mercy and one in which Grilo has power, finishes the contextualization of a world unlike the alienating one of the picaresque. Summoning the Compadecida through prayer, João becomes the community savior. Facing his eternal fate is an echo of Proezas, impertinent and this time the riddler rather than the quizzed, asking the figure of Jesus a question he cannot answer. Unlike those he defends in his hero role in the afterlife, his reward is to go back to Earth. While Huck's trickster death is a figurative one, Twain also 
intends it-with Huck escaping Pap's political ranting - as the potential rebirth for a culture. In more an affirmation of norms, Grilo is returned to his exact existence as popular figure. In the zero-sum schematic he has cheated death but wound up where he started. While he and Chicó dream of opening a bakery, in an affirmation of social connection and obligation, Chicó has promised the money from the will to the Virgin Mary if João should escape.

It is possible to see the Quijote as a kind of distant heir to the tradition of the literatura del "loco." In this sense, perhaps Chicó as sonhador is sometimes the "voz de la verdad absoluta e irreprimible" (VILLANUEVA, 1985, p. 502). The deceased dog of the baker's wife is more important to her than her human workers. While Grilo's death is a zero-sum outcome, the clever departure from the mimetic allows for his character to go beyond his social and psychological confines, gaining a cosmological relevance reminiscent of the Trickster. When Grilo cheats death, he is inverting what Chicó has announced in his strange quixotic way at the beginning of Act 2: "Eu, às vezes, chego a pensar que só quem morre completamente é pobre, porque com os ricos a agonia continua por tanto tempo depois da morte, que chega a parecer que ou eles não morrem direito ou a morte deles é outra” (1971, p. 87).

A FIGURA MARGINALIZADA COMO HERÓI DO ARTIFÍCIO:

João Grilo de Ariano Suassuna e Huck Finn de Mark Twain

\section{RESUMO}

A partir de estreitos laços com um passado folclórico e um esforço consciente para dialogar com uma longa herança literária, o escritor brasileiro Ariano Suassuna (1927-2014) e o escritor norte-americano Mark Twain (1835-1910) apresentam protagonistas regionais que podem ser vistos como heróis do artifício, desde a perspectiva da teoria cognitiva e psico-social. Alimentando-se dos modelos do "Trickster" e do "pícaro", a construção dos personagens João Grilo e Huck Finn valoriza as habilidades cognitivas de figuras socioeconomicamente marginalizadas em regiões carentes. Em Auto da Compadecida (1955) e Aventuras de Huckleberry Finn (1884), Suassuna e Twain conseguem destacar essas habilidades criando 
duos de personagens que imitam o contraponto cognitivo entre Dom Quijote de Miguel de Cervantes e Sancho Pança.

Palavras-chave: Ariano Suassuna. Mark Twain. Trickster. Pícaro. Figuras marginalizadas.

LA FIGURA MARGINALIZADA COMO HÉROE DEL ARTIFICIO:

João Grilo de Ariano Suassuna y Huck Finn de Mark Twain

\section{RESUMEN}

Fuertemente influenciados por un pasado folclórico y en un esfuerzo consciente de dialogar con una grande herencia literaria, el brasileño Ariano Suassuna (19272014) y el estadounidense Mark Twain (1835-1910) presentan protagonistas regionales que pueden ser vistos como héroes del artificio desde la perspectiva de la teoría cognitiva y psico-social. Personajes como João Grilo y Huck Finn se alimentan de los modelos del trickster y del pícaro, y su construcción valoriza las habilidades cognitivas de figuras socioeconómicamente marginalizadas en regiones periféricas. En Auto da Compadecida (1955) y Adventures of Huckleberry Finn (1884), Suassuna y Twain destacan estas habilidades criando pares de personajes que imitan el contrapunto cognitivo entre Don Quijote y Sancho Panza.

PALAVRAS CLAVE: Ariano Suassuna. Mark Twain. Pícaro. Trickster. Figuras marginalizadas.

\section{REFERÊNCIAS}

APPERLY, Ian. Mindreaders: The Cognitive Basis of "Theory of Mind". New York: Psychology Press, 2012.

ATAÍDE, João Martins de. As proezas de João Grilo. In: AMARAL, Firmino Teixeira do; ABREU, Márcia (ed.). Antologia de folhetos de cordel amor, história e luta. São Paulo: Editora Moderna, 2005. p. 87-115.

BARROS, Leandro Gomes de. O cavalo que defecava dinheiro. In: MIRANDA, Eduardo. Antologia Cordel da Compadecida. São Paulo: Kairu, 2016. p. 90-192. 
BARROS, Leandro Gomes de. O dinheiro: o testamento do cachorro. In: MIRANDA, Eduardo. Antologia Cordel da Compadecida. São Paulo: Kairu, 2016. p. 40-87.

BOAS, Franz. Introduction to James Teit: Traditions of the Thompson Indians of British Columbia. In: BOAS, Franz. Race, Language and Culture. New York: Macmillan, 1940.

CANAVAGGIO, Jean. Las bufonadas palaciegas de Sancho Panza. Criticón, n. 127, p. 129-141, 2016.

DENNETT, Daniel C. Brainstorms: Philosophical Essays on Mind and Psychology. Cambridge: MIT Press, 2017.

EVANS, Robert. The Trickster Tricked: Huck Comes Out of the Fog in Mark Twain's The Adventures of Huckleberry Finn. In: BLOOM, Harold; HOBBY, Blake. New York: Bloom's Literary Criticism, 2010. p. 1-8.

GUILLÉN, Claudio. Toward a Definition of the Picaresque. In: GUILLÉN, Claudio. Literature as System: Essays toward the Theory of Literary History. New Jersey: Princeton University Press, 1971.p. 71-106.

JUNG, C.G. On the Psychology of the Trickster Figure. Archetypes and the Collective Unconscious. Traduzido por R.F.C. Hull. New York: Routhedge \& Kegan Paul, 1981. p. 255-272.

KENT, John P. \& GAUNT, J. L. Picaresque Fiction: A Bibliographic Essay. College Literature, v. 6, n. 3, p. 245-270, 1979.

MIRANDA, Eduardo. Antologia Cordel da Compadecida. In: MIRANDA, Eduardo. Antologia Cordel da Compadecida. São Paulo: Kairu, 2016.

QUEIROZ, Rachel. Um romance picaresco? Romance d'A Pedra do Reino e o Príncipe do Sangue do Vai-e-Volta. Rio de Janeiro: Nova Fronteira, 2017.

SANTOS, Idelette Fonseca dos. Em demanda da poética popular: Ariano Suassuna e o movimento armorial. Campinas: Editora da Unicamp, 1999.

SIMMONS, Victoria G. Tricksterism in Popular Traditions. 2005. 269 f. Tese (Doutorado em Folklore and Mythology) - University of California, Los Angeles, 2005. Disponível em: https://search.proquest.com/dissertations-theses/ tricksterism-popular-traditions $/$ docview $/ 305032958 /$ se- 2 ? accountid= 14522 . Acesso em: 28 Dec. 2020.

SLATER, Candace. Stories on a String: The Brazilian Literatura de Cordel. Berkeley: University of California Press, 1982. 
SMITH, David L. Why We Lie: The Evolutionary Roots of Deception and the Unconscious Mind. New York: St. Martin’s Griffin, 2007.

SUSASSUNA, Ariano. A Compadecida e o romanceiro nordestino. In: JÚNIOR NEWTON, Carlos (Org.). Almanaque armorial. Rio de Janeiro: José Olympio, 2008. p. 173-188.

SUSASSUNA, Ariano. Auto da Compadecida. Rio de Janeiro: Agir, 1971.

TOPA, Francisco. A história de João Grilo: do conto popular português ao cordel brasileiro. Revista da Faculdade de Letras: Linguas e Literaturas, v. XII, p. 245-274, 1995. Disponível em: https://sigarra.up.pt/flup/pt/pub_geral.pub_view?pi_ pub_base_id=73341. Acesso em: 28 Dec. 2020.

TWAIN, Mark. On the Decay of the Art of Lying. In: TWAIN, Mark. The Complete Humorous Sketches and Tales of Mark Twain. Garden City: Double Day, 1985. p. 503-508.

TWAIN, Mark. The Complete Novels. Garden City: Double City, 1964.

VASSALLO, Lygia. O sertão medieval: origens europeias do teatro de Ariano Suassuna. Rio de Janeiro: Francisco Alves, 1993.

VILLANUEVA, Francisco Márquez. Literatura Bufonesca o Del 'Loco' Nueva Revista De Filología Hispánica, v. 34, n. 2, p. 501-528, 1985. Disponível em: www. jstor.org/stable/40298680. Acesso em: 28 Dec. 2020.

WALCZYK, Jeffrey; HARRIS, Laura; DUCK, Terri; MULAY, Devyani. A Social-Cognitive Framework for Understanding Serious Lies: ActivationDecision-Construction-Action Theory. New Ideas in Psychology, v. 34, p. 22-36, 2014. Disponível em: https://doi.org/10.1016/j.newideapsych.2014.03.001. Acesso em: 28 Dec. 2020.

ZUNSHINE, Lisa. What Mary Poppins Knew: Theory of Mind, Children's Literature, History. Narrative, v. 27, n. 1, p. 1-29, 2019.

Submetido em 04 de janeiro de 2020

Aceito em 15 de janeiro de 2020

Publicado em 14 de fevereiro de 2021 